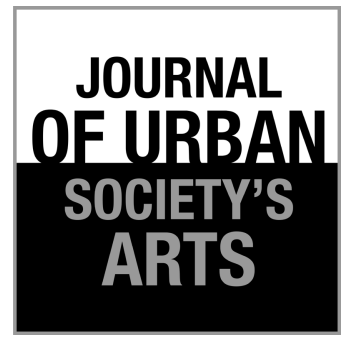

Volume 1 Nomor 2, Oktober 2014: 121-134

\title{
Ikonografi Arsitektur dan Interior Masjid Kristal Khadija Yogyakarta
}

Rony

Jurusan Desain, Politeknik Negeri Samarinda

Jl. Ciptomangunkusumo, Kampus Gunung Lipan, Samarinda 75121

Telp.085246870382,E-mail: iron_082@yahoo.co.id

\begin{abstract}
ABSTRAK
Masjid Kristal Khadija (MKK) adalah sebuah masjid yang berada di kompleks Yayasan Budi Mulia Dua di Yogyakarta. Masjid ini memiliki keunikan pada arsitektur dan desain interiornya. MKK sebagai karya seni akan dikaji dengan metode ikonografi. Metode ini adalah suatu studi untuk mengungkapkan makna dari suatu karya seni dengan tahapan-tahapan, yakni deskripsi praikonografi, analisis ikonografi, dan interpretasi ikonologi. Ketiga proses tahap kajian tersebut bersifat prerequisite atau prasyarat dari tahapan satu ke tahapan selanjutnya. Hasil penelitian pada tahap deskripsi praikonografi bahwa wujud arsitektur dan interior MKK memiliki ciri-ciri masjid bergaya Persia, tetapi masjid ini bukan termasuk tipe hipostyle karena bangunan masjid yang berdiri sendiri dan tidak dilengkapi riwaqs. Analisis ikonografi menghasilkan makna yang ditunjukkan oleh tema feminin dengan konsep material kaca cermin yang diasosiasikan aktivitas kaum wanita, yakni bersolek. Interpretasi ikonologi dihasilkan makna secara simbolis bahwa MKK merepresentasikan ide dan gagasan tokoh dibaliknya. Penafsiran makna ini dapat menambah muatan filosofi MKK sebagai ikon kebanggaan Yayasan Budi Mulia Dua.
\end{abstract}

Kata kunci: arsitektur, interior, Masjid Kristal Khadija, ikonografi

\begin{abstract}
The Iconographic on the Architecture and Interior of Masjid Kristal Khadija Yogyakarta. The Masjid Kristal Khadija is a mosque located in a high school complex under the auspices of the Budi Mulia Dua in Yogyakarta. This mosque is unique in its architecture and interior design. The mosque as a work of art is analyzed by the method of iconography. This method is a study to reveal the meaning of a work of art with the stages namely; pre-iconographical description, iconographical analysis, and iconological interpretation. There is a prerequisite relationship among those stages, meaning that the first stage has to be conducted before the second and the second has to be completed before the last one. The result of the pre-iconographical description stage shows that the architecture and interior of Kristal Khadija is characterized by the Persian style mosque, yet it is not a hypostyle mosque as it is a stand-alone mosque without riwaqs. The iconographical analysis of the mosque indicates that it was built under the feminine theme shown by the use of mirror glass as its material concept that is associated with women's activity, i.e. dressing up. The iconological interpretation generates a symbolic meaning that Masjid Kristal Khadija represents the ideas of the figures behind it. The interpretation of its meaning may add philosophical values to this mosque as an icon of Budi Mulia Dua Foundation pride.
\end{abstract}

Keywords: architecture, interior of mosque, Masjid Kristal Khadija, iconographic study 


\section{Pendahuluan}

Masjid merupakan simbol budaya Islam dan juga wadah untuk bersosialisasi bagi umat Islam, seperti yang dicontohkan Rasulullah SAW, bahwa beliau menjadikan masjid sebagai basis dakwah serta interaksi sosial beliau terhadap umat Islam yang menerima ajarannya. Dalam sejarah Islam masjid banyak dibangun dalam bentuk dan rupa yang artistik. Titik puncak kejayaan Islam yang diperlihatkan dari segi karya arsitekturnya setelah Rasulullah SAW wafat adalah pada masa pemerintahan kekhalifahan Abbasiyah pada masa 737-961M (Ansary, 2012: 146-161).

Masjid Kristal Khadija (MKK) yang dibangun di kompleks sekolah SMP-SMA Internasional Budi Mulia Dua Panjen Yogyakatra yang terlihat anggun dan indah dengan desain fasade yang dihiasi beragam pernik-pernik kristal (kaca). Ide pembangunan masjid ini pertama kali dicetuskan oleh Ibu Hj. Kusnasriyati Sri Rahayu Amien Rais (Bu Amien), yang kemudian kini menjadi hasil karya seni arsitektur tinggi karena membutuhkan keterampilan tersendiri ketika memasang kristalkristal dan marmer di berbagai bagian bangunan masjid (Elisa, 2009).

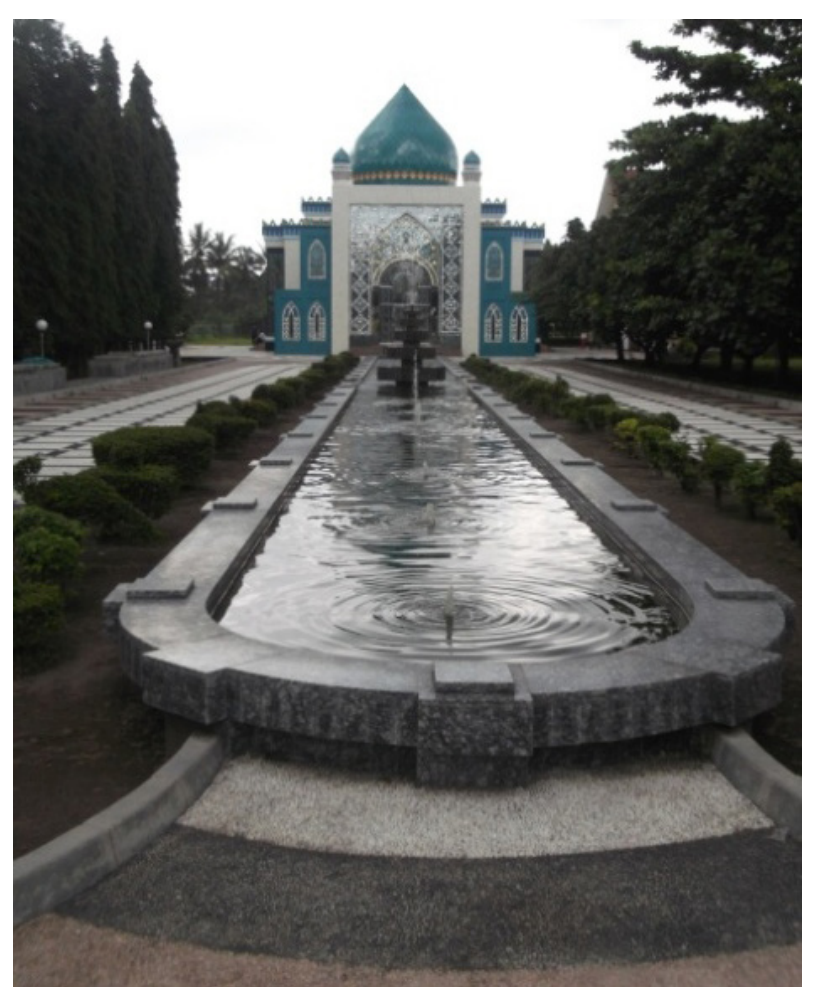

Gambar 1. Masjid Kristal Khadija Yogyakarta. (Sumber: Dokumentasi Rony, Februari 2014)
MKK yang baru diresmikan pada tanggal 4 Mei 2013 lalu menjadi ikon penting bagi Yayasan Budi Mulia Dua. Acara peresmian banyak dihadiri oleh berbagai kalangan termasuk para pejabat penting dan tokoh masyarakat lainnya. Dibangunnya MKK ini tidak lepas dari perjalanan eksistensi yayasan yang memfokuskan diri pada pembinaan pribadi manusia melalui pendidikan (http://budimuliadua.com, 2014).

MKK memiliki keunikan dan karakteristik yang berbeda dengan masjid sebelumnya di Yogyakarta. Secara keseluruhan bentuk masjid sebenarnya tidak jauh berbeda dengan masjid pada umumnya. Yang membuat unik adalah ornamenornamen kristal yang diaplikasikan pada bagian struktur ruangan masjid dan memiliki nilai artistik yang tinggi. Ornamen kristal sangat mendominasi pada langit-langit serambi masjid dan area salat (liwan). Jendela-jendela di bagian atas dinding yang berfungsi sebagai tempat memasukkan cahaya dihiasi dengan kaca patri warna-warni yang bermotif wajik dan tumbuh-tumbuhan.

Wujud fisik bangunan yang berhiaskan dengan kristal dan berbagai ornamen yang unik pada bangunan MKK ini tentunya memiliki makna baik hubungannya dengan yayasan maupun dengan masyarakat sekitar, maka diyakini cukup relevan jika menggunakan pendekatan ikonografis untuk mengungkap makna-makna tersebut. Karakter dan keunikan arsitektur masjid ini merupakan sebuah gagasan yang terinspirasi dari sosok isteri pertama Rasulullah SAW, dengan kemuliaan akhlak

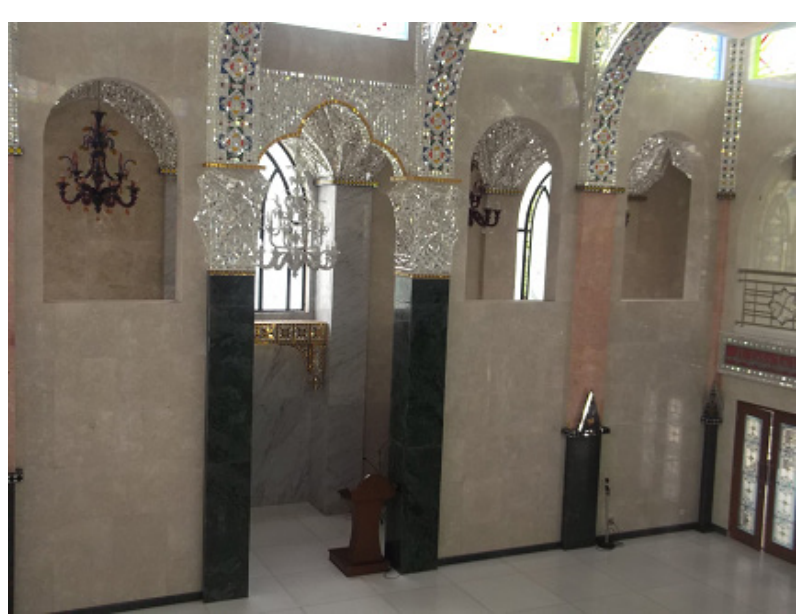

Gambar 2. Interior Liwan dengan Mihrab dan Mimbar di dalam Masjid Kristal Khadija Yogyakarta. (Sumber: Dokumentasi Rony, Februari 2014) 
dan sosok pribadi beliau. Simbol dan ikon yang dimunculkan memiliki keunikan serta karakteristik yang dirasakan mengandung nilai-nilai filosofi yang mendalam. Melalui simbol dan ikon masjid kristal ini, penggagasnya serasa ingin menyampaikan pesan-pesan moral bagi generasi penerus, terutama bagi masyarakat sekolah yang ada di sekitar.

Berdasarkan uraian yang dikemukan di atas, MKK dibangun bukan bertujuan hanya untuk menunjukkan kemegahannya yang menyilaukan mata, melainkan berusaha untuk menyampaikan pesan-pesan moral yang penting bagi kehidupan umat manusia terutama umat Islam. Berpegang pada pendekatan Erwin Panofsky melalui kajian ikonografi dan makna dapatlah dirumuskan permasalahan yang akan diangkat pada penelitian ini, sebagai berikut: (1) Apa makna primer (makna faktual dan makna ekspresional) yang terdapat pada arsitektur dan interior MKK Yogyakarta?, (2) Apa makna konvensional terkait tema dan konsep yang terdapat pada arsitektur dan interior MKK Yogyakarta?, (3) Apa makna intrinsik yang ingin disampaikan dari arsitektur dan interior MKK Yogyakarta?

Teori pokok sering diakui sebagai pisau bedah untuk mengurai dan mendekati objek yang diteliti dalam upaya mengungkapkan permasalahan yang dianggap sebagai penyelesaiannya. Dalam hal ini digunakan pendekatan ikonografi dan ikonologi dari Erwin Panofsky (1955). Berikut kerangka teori yang digunakan dalam penelitian ini.

Erwin Panofsky (1955) menjelaskan bahwa untuk memahami dan mengkaji makna suatu karya seni, tidak terlepas dari tiga tahapan atau tingkatan yang harus dikaji. Arsitektur masjid merupakan salah satu karya seni rupa yang memiliki peranan penting dalam perkembangan kesenian Islam (Situmorang, 1993: 20). Arsitektur kadang dikenal sebagai dasar dari seni rupa "The mother of the art". Keunikan arsitektur di antara karya seni adalah dalam pemenuhan praktis untuk kebutuhan pokok, dengan peranannya sebagai seni yang nyaris tak diduga oleh produk yang dihasilkannya (Pile, 1988: 389). Menurut Situmorang (1993: 24-27), bagian-bagian atau elemen arsitektur masjid yang menarik untuk dikaji lebih lanjut meliputi; (1) Mihrab, (2) Mimbar, (3) Liwan, (4) Sahn, (5)
Fawwarah, tempat untuk berwudlu, (6) Menara atau minaret, (7) Qubhat atau kubah, (8) Pintu masuk masjid, (9) Teras atau serambi, (10) Dikke atau tempat wakil imam (bilal). Kubah masjid ada yang menganggap bukan elemen asli dari arsitektur masjid karena elemen arsitektur ini sudah ada sebelum Islam, namun secara regional kubah ini selalu dikembangkan dan sering digunakan pada arsitektur masjid (Sumalyo, 2000: 658-660 dan Sopandi, 2013: 146).

Hubungan desain interior dengan arsitektur begitu erat dan tidak terbantahkan. Sebuah bangunan dirancang mengikuti ruang dalam yang sejalan dengan bentuk tampilan eksteriornya (Pile, 1988: 389). Berkenaan dengan hal tersebut desain interior dirancang untuk memenuhi kebutuhan sebuah fungsi bangunan yang terlihat dari luarnya. Sebagaimana yang diungkapkan oleh Francis DK. Ching (1996: 46) bahwa desain interior yang disusun secara teratur bagian demi bagiannya menjadi satu tatanan yang utuh dengan maksud dan tujuan tertentu. Elemen-elemen yang dipilih ditata menjadi pola tiga dimensi sesuai dengan garis-garis besar fungsi, estetika dan perilaku penggunanya. Elemen-elemen interior tersebut di antaranya lantai, penutup lantai, dinding, langitlangit, jendela, pintu, tangga, perapian, perabot ruang, peralatan lampu, dan aksesoris ruangan (Ching, 1996:160-276). Dalam hal ini elemenelemen interior akan menjadi bagian penting dalam kajian ikonografi pada sebuah interior masjid.

Unsur-unsur dari arsitektur dan desain interior masjid tersebut akan dikaji dengan ikonografi dan ikonologi yang diperkenalkan oleh Erwin Panofsky (1955), guna memahami dan mengkaji makna yang tersimpan di dalamnya. Dengan tiga tahapan yang perlu dikaji, yakni tahap yang pertama adalah deskrpisi praikonografi (pre iconographical description), tahap yang kedua adalah analisis ikonografis (iconographical analysis), dan tahap yang ketiga adalah interpretasi ikonologis (iconological interpretation) (Panofsky, 1955: 26-40). Ketiga tahap tersebut memiliki hubungan prerequisite atau prasyarat dari tahapan satu dengan tahapan berikutnya. Perangkat dan tahapan-tahapan kajian ikonografi dan ikonologi tersebut terangkum dalam tabel 1 . 


\begin{tabular}{cll}
\hline No. & \multicolumn{1}{c}{ Objek Interpretasi } & \multicolumn{1}{c}{ Aksi Interpretasi } \\
\hline I. & $\begin{array}{l}\text { Pokok bahasan primer atau alami (A) faktual, } \\
\text { (B) ekspresional, menyusun dunia motif artistik. }\end{array}$ & $\begin{array}{l}\text { Deskripsi praikonografi (analisis pseudofor- } \\
\text { mal) }\end{array}$ \\
II. $\begin{array}{l}\text { Pokok bahasan sekunder atau konvensional, } \\
\text { menyusun dunia gambar, cerita, dan alegori. }\end{array}$ & Analisis ikonografis \\
III. $\quad \begin{array}{l}\text { Makna intrinsik atau isi, menyusun dunia nilai } \\
\text { "simbolis" }\end{array}$ & Interpretasi ikonologis \\
\hline
\end{tabular}

Tabel 1. Objek dan Aksi Interpretasi. (Sumber: Panofsky, 1955)

Alat Interpretasi

Pengalaman praktis (rasa familier dengan objek dan peristiwa)

Pengetahuan tentang sumber literal (rasa familier dengan tema dan konsep khusus)

Intuisi sintetis (rasa familier dengan tendensi esensial dari pikiran manusia); dikondisikan oleh psikologi personal dan "weltanschauung"
Prinsip Korektif dari Interpretasi (Sejarah Tradisi)

Sejarah seni (pandangan ke dalam cara di mana, menurut kondisi sejarah yang bervariasi, objek dan peristiwa dinyatakan alam bentuk

Sejarah tipe/jenis (pandangan terhadap cara di mana, di bawah kondisi sejarah yang bervariasi, tema dan konsep khusus dinyatakan melalui objek dan peristiwa)

Sejarah gejala kultural (pandangan ke dalam cara di mana di bawah kondisi sejarah yang bervariasi, tendensi umum dan esensial dari pikiran manusia dinyatakan melalui tema dan konsep khusus)

Tabel 2. Alat dan Prinsip Korektif dari Interpretasi. (Sumber: Panofsky, 1955)

Panofsky (1955: 41) juga merumuskan kerangka konfirmasi yang dapat menjadi prinsip korektif dari setiap fase analisis guna mempertajam analisis dari masing-masing tahapan tersebut, seperti yang dipaparkan dalam tabel 2 .

Pada tahap praikonografi berisi respons awal pada aspek tekstual yang berada dalam batasan motif artistik. Motif artistik merupakan ungkapan yang tersusun dari pokok bahasan primer atau alami, yang dibagi ke dalam faktual dan ekspresional. Makna faktual diperoleh melalui identifikasi bentuk yang tampak pada objek maupun perubahannya melalui aksi dan peristiwa tertentu. Makna ekspresional dipahami dengan cara mengungkap empati dari kemampuan mengamati kebiasaan dan rasa familier terhadap objek dan peristiwa. Mengidentifikasi hubungan antara bentuk-bentuk dan peristiwaperistiwa dapat menjadikan kualitas ekspresional sebagai karakter atau bahasa tubuh objek (Panofsky, 1955: 33-34).

Dalam upaya untuk mempertajam deskripsi tekstual ini diperlukan kerangka konfirmasi dengan prinsip korektif interpretasi melalui sejarah gayagaya masjid. Konsep gaya merupakan bagian yang tidak dapat dihindari dalam kajian seni sehingga memerlukan teori pendukung tentang gaya. Dalam mendeskripsikan konfirmasi sejarah gaya masjid ini akan digunakan pendekatan perspektif gaya masjid (Situmorang, 1993) dan arsitektur masjid (Sumalyo, 2000).

Dalam proses analisis tahap kedua, yaitu analisis ikonografi merupakan tahap untuk mengidentifikasi makna sekunder. Proses ini merupakan kelanjutan pembacaan arti dari aspekaspek tekstual sebelumnya yang melalui tahap ini dihubungkan dengan tema dan konsep. Untuk melihat itu, diperlukan pengamatan dengan melihat hubungan bentuk elemen-elemen interior dan tema serta konsepnya dalam kebiasaan pengalaman praktis. Lebih dari itu, diperlukan kebiasaan pengalaman melihat hubungan konsep dan tema dari karya seni yang diperoleh dari berbagai imaji, sumber literer, dan alegori (Panofsky, 1955:35).

Ketajaman analisis ikonografi ini dapat 
dicapai melalui kerangka konfirmasi dengan prinsip korektif interpretasi sejarah tipe. Sejarah tipe merupakan kondisi-kondisi sejarah yang memengaruhi tentang konvensi suatu tema atau konsep yang diekspresikan dalam objek-objek dan peristiwa spesifik dan berlaku pada suatu masa dan wilayah (Panofsky, 1955: 40). Dalam hal ini sejarah tipe arsitektur dan interior MKK akan ditinjau tipe-tipe yang berkembang dalam rentang masa yang sejajar dari berbagai wilayah.

Tahap ketiga adalah tahap interpretasi ikonologis, merupakan tahapan yang paling esensial untuk memahami makna intrinsik atau isi dari sebuah karya seni. Setelah melalui pemahaman lewat deskripsi praikonografi dan analisis ikonografi, maka dalam tahap ini diperlukan kemampuan mental yang disebut dengan intuisi sintesis dalam memahami simbol. Intuisi sintesis menyangkut tendensi esensial pemikiran psikologi personal dan weltanschauung (pandangan hidup) pencipta karya (Panofsky, 1955:41). Pemahaman mengenai makna intrinsik yang terdapat dalam sebuah objek diperoleh dengan mengungkapkan prinsip-prinsip dasar yang kemudian dapat menunjukkan perilaku sikap dasar dari sebuah bangsa, kurun waktu, strata sosial, ajakan religious, atau filosofis tertentu.

Dalam mencapai ketajaman interpretasi ikonologis ini, kerangka konfirmasi dengan prinsip korektif interpretasi sejarah kebudayaan yang membentuk simbol-simbol tersebut sangat diperlukan. Oleh karena itu, perlu ditinjau melalui berbagai simtom atau gejala yang ada di sekitar objek maupun penciptanya, yang merujuk pada psikologi dan pandangan hidup masyarakat penyangganya (Panofsky, 1955: 41).

\section{Pembahasan}

Pembahasan dalam penelitian ini elemen arstitektur dan interior masjid dibatasi pada bagianbagian utama pada Masjid Kristal Khadija, yaitu: (1) Mihrab, (2) Mimbar, (3) Liwan atau ruang shalat, (4) Menara atau minaret, (5) Qubhat atau kubah, (6) Pintu masuk masjid dan ruang Iwan, dan (7) Teras atau serambi serta ditambah (8) Fawwarah, pancaran air atau kolam air. Keberadaan bagian-bagian ini memiliki peranan dan ciri khas yang menarik untuk diteliti serta satu sama lainnya membentuk interpretasi yang akan diungkapkan dalam penelitian ini sesuai dengan tujuan dari metode ikonografi dari Erwin Panofsky.

\section{Deskripsi Pra Ikonografi}

Deskripsi praikonografi merupakan bahasan primer yang mengungkapkan makna faktual dan ekspresional dari aspek tekstual objek yang dikaji. Pembahasan tahap praikonografi ini berisi tanggapan awal pada aspek tekstual yang ada dalam batasan motif artistik. Motif artistik merupakan makna primer yang terbentuk dari makna faktual dan ekspresional. Makna faktual dipahami dengan mengidentifikasi bentuk yang tampak pada objek. Identifikasi dapat dilakukan dengan mengamati konfigurasi unsur-unsur bentuk murni atau membaca yang tampak seperti garis, bentuk, warna, material dan teknik, dan objek-objek representasi alami seperti manusia, binatang, tumbuhan, dan benda peralatan. Adapun makna ekspresional dipahami dengan cara mengungkap empati dari kemampuan mengamati kebiasaan dan rasa familier terhadap objek dan peristiwa. Mengidentifikasi hubungan antara bentuk-bentuk dan peristiwa-peristiwa dapat menjadikan kualitas ekspresional sebagai karakter atau bahasa tubuh objek (Panofsky, 1955:33-34).

Identifikasi objek yang berupa deskripsi tekstual ini akan didukung kerangka konfirmasi untuk mempertajam tahapan analisis ini dengan prinsip korektif interpretasi melalui sejarah gaya. Sejarah gaya akan dikonfirmasi dengan melihat sejarah gaya-gaya perkembangan masjid dengan melihat dari hasil identifikasi dari makna faktual dan ekspresional yang dilakukan sebelumnya.

MKK memiliki mihrab yang cukup unik dengan luas ruangnya mencapai $12.15 \mathrm{~m}^{2}$. Mihrab diapit dua ruang, yakni sebelah kanan (utara) ruang persiapan imam/khotib, sedangkan sebelah kiri (selatan) ruang sound system. Lantai pada ruang mihrab menyatu dengan lantai liwan/ruang salat, bahan lantai yang berwarna putih terbuat dari marmer prada-white, tanpa menggunakan penutup lantai sajadah khusus untuk imam. Dinding pada ruang mihrab dilapisi tile marmer berwarna whitemarble dengan motif natural, bahan yang sama untuk melapisi dinding pada ruang liwan. Langit- 


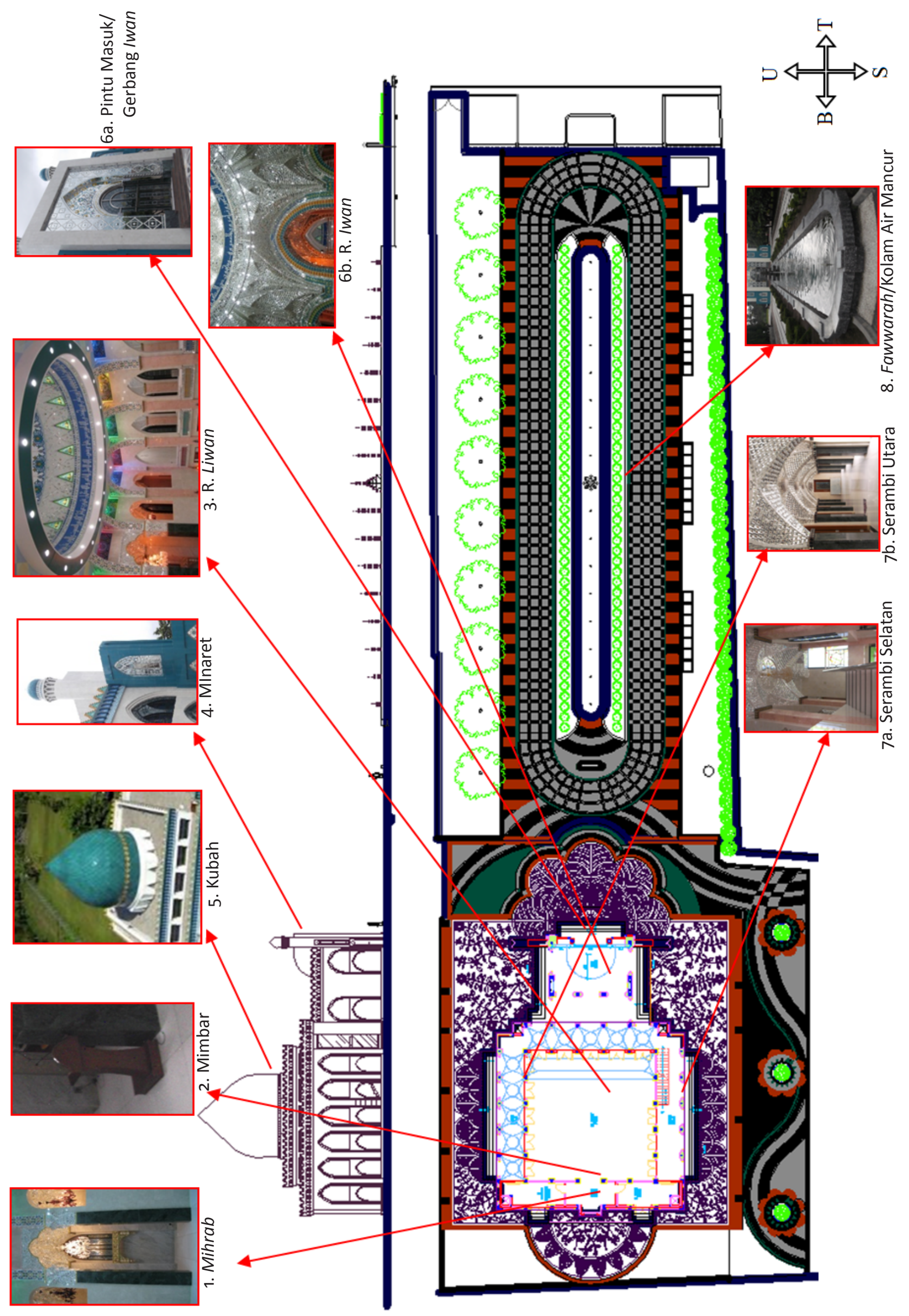

Gambar 3. Bagian-bagian Masjid yang akan dianalisis. (Sumber: Di olah oleh Rony, 2014) 
langit mihrab dihiasi ornamen muqarnash kristal kaca yang menyatu dengan langit-langit yang ada di sisi selatan dan utara ruang.

Mimbar yang ada dalam MKK memiliki bentuk yang cukup sederhana, yakni berupa podium terbuat dari kayu dan dilengkapi alat pengeras suara (mikrofon). Mimbar ini terlihat dibuat cukup ramping dengan kaki mimbar berupa tumpukan papan yang dibentuk persegi, badan mimbar yang menyangga meja dibentuk melengkung ke dalam. Mimbar ini di-finishing dengan tetap memperlihatkan serat-serta kayunya.

Liwan pada MKK berupa ruangan persegi empat dengan luas lantai $156.25 \mathrm{~m}^{2}$. Lantai ruang liwan ini berwarna putih dari bahan marmer, yakni marmer prada-white dengan ukuran $80 \times 80 \mathrm{~cm}$. Bagian belakang dan samping utara ruang liwan ini ditambahkan lantai mezzanine yang berfungsi untuk menambah kapasitas daya tampung masjid. Seluruh bagian dinding ruang liwan ini dilapisi tile marmer yang berwarna white-marble yang sama dengan dinding ruang mihrab. Langit-langit liwan terdapat ceruk kubah utama yang berdiameter dalam 7meter, bagian lis bawah berhiaskan kaligrafi Al Qur'an Surah An Nur ayat 35:

"Allah pemberi cahaya kepada langit dan bumi. Perumpamaan cahaya Allah, adalah seperti sebuah lubang yang tak tembus, yang di dalamnya ada pelita besar. Pelita itu di dalam kaca dan kaca itu seakan-akan bintang yang bercahaya seperti mutiara, yang dinyalakan dengan minyak dari pohon zaitun yang tumbuh tidak di sebelah timur sesuatu dan tidak pula di sebelah baratnya, yang minyaknya saja hampir-hampir menerangi, walau tidak disentuh api. Cahaya di atas cahaya (berlapis-lapis), Allah membimbing kepada cahaya-Nya siapa yang Dia kehendaki, dan Allah memperbuat perumpamaanperumpamaan bagi manusia, dan Allah Maha Mengetahui segala sesuatu".(QS.An Nur [24]:35)

Langit-langit ruang liwan dilapisi plafon yang dicat dengan motif geometris permainan garis yang membentuk belah ketupat dengan dicat berwarna muda/krem (kuning, hijau dan biru). Ruangan liwan ini banyak sekali terdapat hiasan kaligrafi selain yang terdapat di ceruk kubah utama, bagian dinding utara dan selatan serta mezzanine (timur) juga terdapat 15 ornamen kaligrafi yang diambil dari ayat-ayat Alquran, di antaranya; Q.S Al Maa'idah:3, Q.S. Al An'am:162 \& 163, Q.S. Al Ankabut:69, Q.S. At Thalaq:7, Q.S. Al Baqarah:152 \& 153, Q.S. Ali Imron:139, Q.S. Al Furqaan:67, Q.S. Ash Shaff:4, Q.S. Ibrahim:7. Ayat-ayat Al Qur'an tersebut dipilihkan oleh bpak Prof. Dr. Amien Rais yang dimaksudkan menyampaikan pesan agama (tausiyah) tentang dalil-dalil Islam dan bagaimana cara sikap hidup seorang muslimin sebenarnya.

Serambi MKK terletak di sebelah utara dan selatan dari ruang utama salat/liwan. Lantai mezzanine yang menjadi lantai kedua dalam area masjid juga berfungsi sebagai serambi masjid. Ruang serambi masjid ini menyatu dengan ruang iwan yang berada di depan (timur). Terdapat banyak ornamen muqarnash yang menghiasi ruang serambi ini dan bahkan dapat dikatakan seluruh langitlangit serambi ini dihiasi dengan kristal kaca. Tiap antara kolom-kolom dinding serambi dan dinding liwan dilengkapi ornamen muqarnash kristal kaca dengan satu titik lampu kristal. Lantai serambi berupa marmer putih memiliki elevasi penurunan dari ruang utama sholat setinggi $2 \mathrm{~cm}$. Tiap kolomkolom serambi ditutup dengan marmer hijau dan marble putih.

Pintu gerbang masuk MKK berbentuk tembok kaca persegi yang dibingkai konstruksi beton dengan dilapisi marmer putih berukuran tinggi 9 meter. Pada sisi kiri dan kanan tembok ini terdapat tembok yang berupa sayap dengan bentuk secara presisi memiliki karakter yang sama. Pada tembok pintu gerbang terdapat menara dengan ujung bentuk kubah yang menyatu konstruksi iwan sehingga terlihat kecil dan menyerupai tanduk karena terletak pada masing-masing ujung atas dinding iwan. Pintu kaca patri dari gerbang iwan ini berupa pelengkung patah yang dibingkai dinding kaca persegi yang diberi ornamen 2D dan 3D dengan motif geometris. Bagian dalam gerbang iwan terdapat tiga pintu pelengkung yang terletak di tengah-tengah antara gerbang iwan dengan serambi depan (timur ruang liwan). Pada lantai ruang iwan yang berbahan sama dengan serambi 
terdapat dihias denga ornamin permainan polapola lantai yang berbentuk geometris. Bagian dinding dalam gerbang iwan dihias ornamen kaca kristal hingga bagian langit-langit.

MKK sebenarnya dibangun tanpa minaret yang terpisah. Minaret yang dimiliki masjid kristal ini hanya terdapat pada ujung dinding gerbang iwan masjid dengan ukuran yang tidak terlalu tinggi dan kecil sehingga sepintas tampak menyerupai tanduk.

Kubah pada MKK ada dua buah kubah, yakni (1) kubah utama yang terletak di atas ruang liwan dan (2) kubah kedua terletak di atas ruang iwan yang berbentuk setengah kubah atau 1/4 lingkaran. Kubah utama MKK ini berwarna hijau kebiruan yang di bagian bawahnya terdapat ornamen lis berwarna kuning dari plat enamel yang sama.

Fawwarah atau kolam air mancur di depan MKK bukan sebagai tempat berwudhu, melainkan lebih berfungsi sebagai penghias (fungsi estetik) dan memberikan kesejukan pada area taman. Kolam air mancur terdapat 17 (tujuh belas) titik air mancur pada titik yang di tengah dihias undakan dengan lima tingkat yang bila dilihat dari atas berbentuk persegi delapan. Persegi delapan ini kombinasi dari dua buah bentuk persegi empat.

Ornamen kristal kaca pada langit-langit ruang mihrab, ruang serambi, dan ruang iwan yang merupakan pengembangan bentuk muqarnash pada arsitektur masjid bergaya Persia. Ornamen muqarnash kristal kaca membuat ruang serambi dan ruang iwan akan memencarkan cahaya lampu ke segala arah. Hal ini mengekspresikan ruang ragawi yang selalu memperlihatkan kenikmatan dunia yang pancarannya tidak terarah dan akan selalu menyilaukan manusia. Kesan sakral dan keilahian yang muncul pada ruang liwan didukung dengan ornamen kaligrafi dari ayat-ayat Al Qur'an yang bermakna tentang kebesaran dan keagungan Allah SWT serta perintah dan larangan yang harus dipatuhi oleh manusia sebagai hamba-Nya.

Secara keseluruhan identifikasi dari bagianbagian masjid di atas memiliki ciri-ciri gaya Persia. Dominasi ornamen kristal kaca dengan bentuk muqarnash pada langit-langit ruang mihrab, ruang serambi, dan ruang iwan. Bentuk pelengkung pada pintu, jendela, pilar-pilar di ruang iwan serta kubah masjid yang berbentuk pelengkung patah merupakan salah satu ciri khas yang sering dijumpai pada arsitektur Persian Style. Kolam air mancur (fawwarah) yang lazim dijumpai pada bangunan masjid tipe hipostyle dikembangkan pada masa bani Seljuk (abad XI) merupakan ciri khas yang tak pernah lepas dengan masjid bergaya Persia. Mimbar masjid yang bentuknya diidentifikasi bukan sebagai salah satu ciri masjid Persia tidak mengurangi kesan keseluruhan gaya arsitektur masjid ini. Masjid ini bukan termasuk tipe hipostyle karena bentuk bangunan yang berdiri sendiri serta tidak memiliki riwaqs/selasar yang mengelilingi shaan sebagai bagian dari bangunan masjid.

Sebagai upaya untuk mencapai ketajaman deskripsi tekstual ini diperlukan kerangka konfirmasi dengan prinsip korektif interpretasi sejarah gaya. Berdasarkan analisis makna faktual dan ekspresional bagian-bagian dari MKK yang telah diuraikan di atas bahwa diidentifikasi memiliki kecenderungan gaya masjid yang bermazhab Persia - Sasanide (Persian Style). Beberapa ahli sejarah mencatat dengan panjangnya masa pemerintahan dan kekuasaan dinasti yang berkuasa di wilayah Iran pada waktu itu memberi pengaruh terhadap perkembangan budaya dan ilmu pengetahuannya, seperti pada masa Sultan Malik Syah (1072-1092 M) yang merupakan sultan dari Bani Seljuk telah menaruh perhatiannya pada upaya menghidupkan api ijtihad dalam dunia Islam. Pada masa beliau ini banyak mendirikan madrasah-madrasah Nizamiyah dan dan Hanafiah, pada masa ini pula muncullah Imam Ghazali seorang filsuf yang terkenal (Wiryoprawiro, 1986: 84).

Menurut Sumalyo (2000: 114-172) perkembangan gaya masjid aliran Persia ini seolah menunjukkan betapa ilmu pengetahuan dan teknologi berkembang pesat pada masa itu. Hal ini dapat dilihat dengan kemampuan menghiasi masjid dengan berbagai dekorasi muqarnash yang demikian rumit. Kondisi alam Persia yang cukup tandus malah menghasilkan banyak batu marmer, basalt, dan granit, beberapa wilayah juga menghasilkan batu bata, keramik dan terakota. Stuco dan batu glazir juga dikembangkan pada masa ini sehingga menghasilkan karya yang bernilai seni tinggi. 
Hampir setiap masjid-masjid besar yang dibangun di Iran selalu dilengkapi dengan madrasah-madrasah ilmu, yang sangat didukung oleh kepala pemerintahan pada masa itu. Selain membangun masjid, bangsa Iran juga banyak mendirikan Turbah (makam) yang indah-indah untuk mengenang dan menghormati tokoh agama terutama kalangan imam yang dihormati dalam Islam aliran Syiah; seperti Turbah Syeik Sayifus di Ardabil, makam Sayidah Maksumah di Qum, makam Imam Riza di Mashhad dan beberapa tokoh lainnya (Sumalyo, 2000; Wiryoprawiro, 1986).

Membangun turbah/makam ini juga memengaruhi bangsa-bangsa Islam lainnya terutama kerajaan Islam dinasti Mughal di India, seperti yang dilakukan Syah Jehan (1628-1658 M) membangun makam Taj Mahal di Agra untuk mengenang salah satu isterinya yang sangat dicintainya yaitu Arjumand Banu Bagam atau lebih dikenal Mumtaz Mahal. Makam Taj Mahal diapit dua bangunan yang berfungsi berbeda, yakni masjid di sebelah kiri dan guest house sebelah kanan. Secara garis besar kompleks Taj Mahal memiliki ciri-ciri bangunan masjid di Persia terutama gerbang iwan dan kubahnya yang telah dikembangkan (Sumalyo, 2000: 399-400).

Kebijakan penguasa menjadi faktor utama, misal pada masa dinasti Saffaviyah yang menetapkan kota Isfahan sebagai pusat pendidikan pada masa itu, membuat sistem politik yang kuat akan berdampak pada sistem pertahanan dan ekonomi yang stabil seperti yang dilakukan Syah Abbas I dari dinasti Saffaviyah (Zuraya, 2012). Dengan kondisi negara yang aman dan stabil proses belajar dari kalangan cendiakiawan akan memberi ruang gerak yang luas untuk mengamalkan dan mengembangkan ilmu pengetahuannya.

\section{Analisis Ikonografis}

Analisis ikonografis merupakan pokok bahasan sekunder atau konvesional, dengan menghubungkan dunia gambar, cerita dan alegori atau lambanglambang yang teridentifikasi sebelumnya. Dalam tahapan kedua ini untuk mengidentifikasi makna sekunder yang dihubungkan dengan tema dan konsep. Oleh karena itu, dibutuhkan pengamatan dengan melihat hubungan bentuk-bentuk dan tema serta konsepnya dalam pengalaman praktis. Selain itu, juga diperlukan kebiasaan pengalaman mengamati hubungan konsep dan tema dari karya seni yang didapat dari berbagai imaji, sumber literatur, dan alegori (Panofsky, 1955: 35).

Identifikasi pertama dari arsitektur dan interior MKK adalah material yang dominan digunakannya, yakni kaca dan cermin. Material kaca banyak digunakan sebagai penutup jendela dan pintu masjid. Material cermin digunakan sebagai penyusun ornamen muqarnash yang dikembangkan oleh tim pembangunan Masjid Kristal Khadija. Muqarnash yang dibuat banyak menghiasi langit-langit interior masjid terutama di ruang iwan dan serambi masjid. Termasuk lampu-lampu yang menghias juga merupakan lampu kristal yang dibuat khusus untuk penerangan interior masjid yang dapat memancarkan cahaya warna-warni. Cermin pada umumnya merupakan salah satu perangkat yang sering digunakan wanita untuk berhias. Dengan konsep banyaknya cermin yang digunakan menunjukkan bahwa karakter material cermin yang merupakan salah satu "perangkat" yang digunakan dalam aktivitas wanita untuk bersolek, maka dari itu masjid ini cenderung bertemakan feminin.

Tema yang ingin diungkapkan dari MKK adalah tema feminin yang dipahami sebagai hadirnya sosok seorang wanita yang mendominasi keberadaannya dalam hal memengaruhi lingkungan sekitar kehidupannya. Dominasi adalah kekuatan dari satu kelompok atau individu terhadap kelompok dan individu lainnya (Humm, 2002: 117). Isu-isu feminin sudah dihembuskan sejak lama, terutama di mana paham ini menaruh perhatian pada kesetaraan gender, membela kaum perempuan yang selalu menjadi korban dari konsep patriarki. MKK diambil dari nama isteri Nabi Muhammad SAW, dianggap merupakan perwakilan dari peran seorang wanita tangguh dan setia mendampingi Nabi dalam berdakwah memperjuangkan tegaknya agama Islam.

Feminin dalam Islam telah dikenal sejak masa klasik, namun sejarah Islam jarang sekali mencatatnya. Sebagaimana yang diutarakan oleh ZTF Pradana (2005) bahwa kesetaraan gender dalam sufisme adalah salah satu genuinitas ajaran sufi karena sementara orang-orang berdebat tentang 
ayat-ayat Alquran yang misogonis (membenci perempuan), namun kaum sufi tenggelam dalam upaya pencarian hakiki tanpa harus terbebani dengan identitas-identitas gender semacam ini. Kesetaraan identitas gender dalam sufisme inilah yang mengarahkan Imam Syafi'i untuk tidak malu-malu "berguru" kepada Sayyidah Nafisah dalam berbagai persoalan agama serta memberikan apresiasi yang positif terhadapnya. Hassan Al Bashri seorang tokoh sufisme menuturkan hubungan keilmuanya dengan Rabi'ah al Adawiyah bahwa "dalam kesehariannya mendialogkan tentang jalan menggapai Tuhan dan kebenaran, tidak terlintas sedikitpun bahwa saya adalah laki-laki dan ia adalah seorang perempuan dan diakhir perbincangan saya merasa sangat rendah terhadap keluasan ilmu agamanya”. Dalam konteks ini tiga orang ahli sufi perempuan yang sering diungkapkan dalam beberapa riwayat, yakni Rabi'ah al Adawiyah, Rabi'ah binti Ismail, dan Sayyidah Nafsiyah. Ketiga tokoh ini dianggap sebagai reprensentasi yang mengaktualkan gerakan feminisme dalam Islam di masa lalu (ZTF, 2002: 137-142).

Dalam upaya untuk mempertajam analisis ini perlu dikonfirmasi kerangka korektif mengenai sejarah tipe. Sejarah tipe yang dimaksud adalah kondisi-kondisi sejarah yang memengaruhi tentang konvensi suatu tema atau konsep yang diekspresikan dalam objek-objek dan peristiwa spesifik dan berlaku pada suatu masa dan wilayah (Panofsky, 1955: 40). Di Indonesia masjid yang mengusung tema dan konsep feminin yang fenomenal pada rentang waktu saat ini bisa ditemui pada Masjid Kubah Emas Dian Al Mahri di Depok, Jawa Barat.

Masjid ini dibangun oleh Hj. Dian Djuriah Maimun Al Rasyid, pengusaha asal Banten, yang telah membeli tanah ini sejak tahun 1996. Masjid ini mulai dibangun sejak tahun 2001 dan selesai sekitar akhir tahun 2006. Kawasan masjid ini sering disebut sebagai kawasan masjid termegah di Asia Tenggara. Masjid Dian Al Mahri memiliki 5 kubah. Satu kubah utama dan 4 kubah kecil. Uniknya, seluruh kubah dilapisi emas setebal 2 sampai 3 milimeter dan mozaik kristal. Emas ini menyimbolkan bahwa karena beliau seorang wanita dan menyukai perhiasan yang terutama berbahan emas. Bentuk kubah utama menyerupai kubah Taj
Mahal (http://id.wikipedia.com).

Nama Masjid Kristal bila ditulis dalam laman web google akan ditemukan masjid kristal yang ada di Malaysia dan MKK di Yogyakarta yang penulis bahas. Berkenaan dengan Masjid Kristal yang ada di Malaysia ini memiliki karakter yang unik dengan hampir seluruhnya eksteriornya ditutupi material kaca dengan konsep modern yang ditunjukkan dengan disematkannya teknologi IT terkini sebgai fasilitas pendukung masjid ini.

Masjid Kristal adalah sebuah masjid yang terletak dalam kawasan Taman Tamadun Islam di Pulau Wan Man, Terengganu. Dinamakan masjid Kristal karena sebagian besar masjid ini terbuat dari kaca dan baja. Masjid ini memiliki luas 2.146 meter persegi dan berkapasitas 700 jamaah. Selain itu, masjid ini juga dilengkapi dengan sarana teknologi dan jaringan WiFi sebagai akses internet guna membaca Alquran elektronik. Pada malam hari Masjid Kristal ini akan bercahaya gemerlap yang menyerupai sebuah kristal yang berwarna-warni yang indah, mungkin inilah yang melatarbelakangi penamaan masjid ini.

\section{Interpretasi Ikonologis}

Interpretasi ikonologis merupakan pengungkapan makna intrinsik atau isi, dengan menyusun nilai "simbolis" dari intuisi sintesis dan sejarah kebudayaan yang terjadi dalam lingkup karya seni yakni; arsitektur masjid. Setelah melalui pemahaman lewat deskripsi praikonografi dan analisis ikonografi, dalam tahap ini dibutuhkan kemampuan mental yang disebut dengan intuisi sintesis untuk memahami simbol. Intuisi sintesis menyangkut tendensi esensial pemikiran psikologi personal dan weltanschauung (pandangan hidup) pencipta karya (Panofsky, 1955: 41).

Uraian pada tahap kedua sebelumnya mengungkapkan tema dan konsep feminin yang berkembang dalam Islam terutama dalam faham sufisme. Sufisme sendiri dipahami sebagai jalan mencari kebenaran yang hakiki dalam upaya mendekatkan diri kepada Allah SWT. Seluruh tahapan sufisme akan bermuara pada gagasan tentang kepasrahan, yakni suatu asumsi bahwa tidak relevannya identitas gender dalam sufisme merupakan suatu tahap dalam upaya kepasrahan kepada Tuhan itu sendiri 
(ZTF, 2005: 141). Sebuah gagasan tentang kepasrahan menurut penulis terasa dekat dengan maksud kata cinta. Kecintaan seseorang akan melahirkan sebuah sikap pasrah yang kadang sangat sulit dipahami oleh pelakunya sendiri.

MKK dalam bentuk simbolisnya merupakan sebuah persembahan, penghargaan, penghormatan, dan rasa kecintaan dari seorang Bapak Prof. Dr. Amien Rais kepada isteri tercintanya, yakni ibu Hj. Kusnasriyati Sri Rahayu Amien Rais. Menurut Siregar (2006: 53) simbolisasi memungkinkan manusia menyampaikan maksudnya sehingga ia dapat dikategorikan dalam suatu cara komunikasi, yaitu "penyampaian". Ide awal pendirian masjid ini memang bermula dari Bu Amien, dalam perjalanannya upaya untuk menemukan konsep dan karakter yang kuat merupakan arahan dari Pak Amien Rais, segala sesuatunya akan selalu diupayakan demi mewujudkan masjid yang indah ini.

Ahmad Fanani dalam profesinya sebagai seorang arsitek yang cukup ternama, beliau memiliki keterikatan secara emosional dan hubungan kekeluargaan terhadap Prof. Amien Rais dan Ibu Hj. Kusnasriyati Sri Rahayu Amien Rais. Lahir dari keluarga yang agamis, yakni dari kalangan kader-kader Muhammadiyah yang taat dalam menjalankan agama telah banyak memengaruhi dalam karya arsitekturnya. Pak Ahmad Fanani pernah belajar arsitektur secara langsung dari Romo Mangun (Y.B. Mangunwijaya) semasa aktif kuliah di Univesitas Gajah Mada Yogyakarta. Sepanjang karier profesionalnya beliau memiliki pergaulan yang luas dengan tokoh-tokoh besar di negara ini serta memiliki pengalaman-pengalaman berarsitektur mumpuni menjadikan beliau sebagai arsitek yang cukup disegani dan dihormati.

Masjid merupakan karya yang paling sering beliau kerjakan di samping karya arsitektur yang lainnya. Setiap karya arsitektur masjid yang beliau rancang selalu menunjukkan ciri khas yang kuat sebagai kunci karakter (ruh) yang selalu dimasukkan dalam karyanya, sebagai contoh Masjid Az-Zikra yang dimiliki oleh Yayasan Az-Zikra asuhan Ustaz Muhammad Arifin Ilham di Sentul, memiliki karakter maskulin yang mencerminkan kepribadian Ustadz M. Arifin Ilham tersebut. Setiap karya arsitekturnya beliau selalu memasukkan nilai- nilai syariat Islam dan filosofi sufisme Islam dalam menyusun massa dan karakter bangunan masjidnya, maka dengan begitu setiap bagian bangunan masjid memiliki hubungan satu sama lainnya. Sufisme yang masuk dalam karakter arsitektur didasari atas bahwa peradaban Islam meninggalkan dua jejak budaya, yakni rohani dan jasmani (materi). Jejak budaya rohani yang dimaksud adalah kalam/ filsafat, tasawuf, dan syar'i. Melalui jejak budaya rohani inilah beliau berusaha menunjukkan bahwa budaya Islam akan dapat terus dihadirkan dalam perwujudan arsitektur masjid yang akan berakulturasi dengan budaya setempat. Dengan demikian, arsitektur masjid tersebut masih akan memperlihatkan karakteristik lokalitasnya walau dikemas dalam budaya Islam. Dengan demikian, beliau memiliki pandangan bahwa kompleksitas penampilan karya arsitektur adalah lambang kompleksitas peradaban masyarakat di tempat mana arsitektur itu berada (Fanani, 2009: 17).

MKK patutlah disebut sebagai simbolisasi dari ketiga tokoh tersebut untuk mengemukakan ide dan gagasannya serta dapat dianggap sebagai salah satu ungkapan budaya masyarakat yang berkembang saat ini. Prof. Dr. Amien Rais sebagai suksesor era reformasi memberikan sentuhan bahwa sebenarnya kita mampu untuk membangun bangsa ini dengan ketulusan serta mengerahkan segenap kemampuan yang kita miliki. Ibu Hj. Kusnasriyati Sri Rahayu Amien Rais pun demikian bahwa dengan berjuang dan istikhomah serta menjaga keharmonisan dengan memberi bekal serta menyiapkan generasi penerus bangsa ini tentu akan dapat mewujudkan cita-cita mulia bangsa yang adil dan makmur. Ir. Ahmad Fanani dengan kemampuan intelektualnya dan kemahirannya meramu ide-ide dari tokoh di belakang MKK menjadi sebuah karya arsitektur yang bernilai tinggi dengan memberikan sentuhan akhir yang cemerlang bagi perwujudan sesuai karakter dan sesuai kondisi sosial budaya bangsa saat ini.

Sebagai kerangka konfirmasi korektif dari analisis interpretasi ikonologi ini, kita dapat melihat sejarah perkembangan budaya yang terjadi pada masa kini. Arsitektur sebagai ungkapan rasa cinta, penghormatan, penghargaan, dan persembahan terhadap seseorang bukan hanya berupa bangunan 
monumen, namun telah menjadi sebuah tren yang cenderung memaknai sebuah karya arsitektur yang dapat mewakili karakter seseorang maupun peristiwa atau pengalaman-pengalaman hidup seseorang. Tren membangun karya arsitektur monumen cenderung didukung dengan kondisi kemapanan sosial dan budaya yang dimiliki kelompok atau komunitas tertentu. Sebagaimana yang dinyatakan oleh Siregar (2006: 119) bahwa arsitektur mencerminkan atau merepresentasikan kekaryaan yang menjadi salah satu kegiatan utama manusia dalam menjalani kehidupannya. Kekaryaan ini representasi arsitekturalnya memiliki tiga kategori, yakni (1) karya fisik, karya sosial, dan karya spiritual..

Masjid At Tin di kompleks Taman Mini Indonesia Indah (selesai dibangun tahun 1999) merupakan sebuah masjid yang dimaksudkan untuk mengenang mendiang isteri mantan Presiden Soeharto (ibu Tien Suharto). Pembangunan masjid At Tin ini selesai di tahun 1999 tepat setelah kekuasaan Presiden Soeharto berakhir, namun untuk tetap mengenang dan mengabadikan 'karya' sosial dan spirit dari seorang ibu negara dibangunlah masjid tersebut.

Arsitektur monumen selain masjid kadang dijumpai cenderung dengan bentuk-bentuk yang tidak "biasa", namun memiliki muatan filosofi yang mendasari karakteristik bangunan tersebut. Bangunan tersebut diharapkan dapat menginterpretasikan wujud penghargaan terhadap seseorang, seperti Museum Purna Bhakti Pertiwi yang dibangun untuk mengenang jasa besar atau "kekaryaan" mantan Presiden Soeharto yang telah lama memimpin bangsa ini. Museum Affandi yang terletak di Yogyakarta didalamnya banyak mengoleksi karya almarhum Affandi yang terkenal mendunia. Museum Tsunami Aceh yang terletak di Jl. Sultan Iskandar Muda Banda Aceh. Museum ini didedikasikan untuk mengenang peristiwa tsunami yang menimpa Banda Aceh Darussalam tanggal 26 Desember 2004. Museum Tsunami Aceh ini sebuah karya arsitektur yang unik, namun sebenarnya lebih fungsional dan edukatif, seperti menampilkan simulasi elektronik gempa bumi Samudra Hindia tahun 2004, foto-foto korban serta kisah dari korban yang selamat. (www.wikipedia.com, 2014).
Berdasarkan arsitektur monumen di atas yang merupakan ungkapan penghargaan, persembahan, dan penghormatan menggambarkan karakter bangunan yang dibuat unik, kadang lebih modern dan nature (alami) sesuai dengan fungsi dan tujuan arsitektur tersebut. Hal ini memperlihatkan kecenderungan ruang gerak berkarya yang lebih leluasa dari para seniman atau arsiteknya. Tren arsitektur yang dibangun untuk mengungkapkan rasa kecintaan, persembahan, penghormatan, ataupun, penghargaan terhadap seseorang telah banyak berdiri dengan menyerap gaya arsitektur dari luar yang dapat mengakomodasi tendesi psikologis personal pencipta atau penggagasnya. Perpaduan tren budaya luar dengan kebudayaan lokal acapkali terjadi sehingga menghadirkan bentuk-bentuk tren arsitektur baru yang lebih unik, hal ini untuk menekankan kesan bahwa dengan keunikan tersebut memori romantisme tentang suatu kekaryaan seseorang akan sukar untuk dilupakan.

Keunikan di sini yang dimaksud kadang berarti sesuatu karya yang baru, belum pernah ada sebelumnya atau sesuatu karya sudah ada tetapi jarang ditemui baik itu hasil perpaduan budaya dari kegiatan dan kreativitas manusia. Hal ini menjadi menarik karena semua karya yang dihasilkan tidak lepas dari kegiatan dan kreativitas manusia itu sendiri dalam upaya menjalani hidupnya. Sebagaimana menurut Siregar (2006: 117), kegiatan dan kreativitas manusia mentransformasikan dirinya terhadap kultur (budaya) kehidupannya.

\section{Simpulan}

Simpulan pertama dari penelitian ini adalah mengenai makna faktual dan ekspresional dari arsitektur dan interior dari Masjid Kristal Khadija. Identifikasi penanda visual pada bagian-bagian masjid, yaitu (1) Mihrab, (2) Liwan atau ruang shalat, (3) Menara atau minaret, (4) Qubhat atau kubah, (5) Pintu masuk masjid dan ruang Iwan, (6) Teras atau serambi, dan (7) Fawwarah (pancaran air atau kolam air) menunjukkan ciri-ciri karakter arsitektur masjid yang bergaya Persia, sedangkan (8) Mimbar masjid yang bentuknya diidentifikasi bukan sebagai salah satu ciri masjid Persia. MKK 
merupakan masjid yang bermazhab Persia Sasanide (Persian Style), tetapi bukan termasuk tipe arsitektur hipostyle karena bangunan utama masjid yang berdiri sendiri serta tidak dilengkapi riwaqs/selasar yang mengelilingi shaan atau taman dengan kolam air.

Secara keseluruhan tampilan MKK ini memiliki ciri-ciri arsitektur masjid bergaya Persia (Persian Style). Aliran Persia ini berkembang pada abad ke-10 hingga ke-18 periode Islam. Pada masa itu merupakan masa kejayaan dinasti kerajaan Islam yang diperlihatkan tingginya seni keindahan bangunan masjid yang dibangunnya. Kebudayaan bangsa Persia pada periode Islam ini tetap bertahan hingga abad terakhir ini, dan menjadi catatan sejarah bahwa pada masa ini pula kebudayaan Islam yang diserap bangsa Persia telah mengalami peningkatan kejayaan dari bidang ilmu pengetahuannya terutama seni arsitektur masjid.

Simpulan kedua adalah makna konvensional tentang tema dan konsep yang membangun karakter dari arsitektur dan desain interior Masjid Kristal Khadija. Identifikasi pertama dari arsitektur dan interior MKK adalah material yang dominan digunakannya, yakni kaca dan cermin. Material kaca banyak digunakan sebagai penutup jendela dan pintu masjid. Material cermin digunakan sebagai penyusun ornamen muqarnash yang dikembangkan oleh tim pembangunan Masjid Kristal Khadija. Dengan konsep kaca cermin yang digunakan menunjukkan bahwa karakter material cermin merupakan salah satu "perangkat" yang digunakan dalam aktivitas wanita untuk bersolek, maka dari itu masjid ini cenderung bertemakan feminin. Tema feminin dalam Islam yang diusung mengarahkan konsep penciptaan karya seni arsitektur yang menghormati sosok seorang wanita dalam perannya memengaruhi kehidupan lingkungan keluarga dan pasangannya. Tema ini akan sering dijumpai pada karya-karya arsitektur masjid yang bergaya Persia, seperti Masjid Taj Mahal di India.

Dalam kerangka korektifnya tema-tema feminin juga sering kali muncul pada arsitektur masjid seperti masjid Dian Al Mahri (Masjid Kubah Emas) yang didasarkan dari karakter tokoh pendirinya, yakni $\mathrm{Hj}$. Dian Djuriah Maimun
Al Rasyid, pengusaha asal Banten yang selesai dibangun tahun 2006. Tema Masjid Dian Al Mahri atau Masjid Kubah Emas mengusung tema feminin dengan konsep material emas yang pada umumnya adalah bahan perhiasan yang digunakan oleh seorang wanita.

Simpulan yang ketiga adalah makna intrinsik yang diungkapkan dalam karya arsitektur dan interior Masjid Kristal Khadija. MKK patutlah disebut sebagai simbolisasi dari ketiga tokoh, yakni Prof. Dr. Amien Rais, Ibu Hj. Kusnasriyati Sri Rahayu Amien Rais, dan Ir. Ahmad Fanani. Karya arsitektur ini dianggap merepresentasikan ide dan gagasan ketiga tokoh tersebut serta sebagai salah satu ungkapan budaya masyarakat yang berkembang saat ini. Berdasarkan tendensi psikologi personal tokohtokoh tersebut, MKK dalam bentuk simbolisnya merupakan sebuah persembahan kasih sayang, kecintaan, penghargaan, dan penghormatan. Dari penelusuran intuisi sintesis yang menyangkut tendensi esensial pemikiran psikologi personal dan weltanschauung (pandangan hidup) dari tokoh pendiri Masjid Kristal Khadija

Dalam kerangka korektif arsitektur yang dibangun untuk menginterpretasikan sebagai ungkapan rasa cinta, penghormatan, penghargaan, dan persembahan terhadap seseorang menjadi sebuah tren yang cenderung memaknai sebuah karya arsitektur yang dapat mewakili karakter seseorang, peristiwa, atau pengalaman-pengalaman hidup seseorang. Tren membangun karya arsitektur monumen cenderung didukung dengan kondisi kemapanan sosial dan budaya yang dimiliki kelompok atau komunitas tertentu. Contoh karya arsitektur yang dapat merepresentasikan karya seseorang dalam wujud arsitekturnya, misalnya Masjid At Tin di kompleks Taman Mini Indonesia Indah (tahun 1999), Museum Purna Bhakti Pertiwi, Museum Affandi yang terletak di Yogyakarta dan Museum Tsunami Aceh yang terletak di Jl. Sultan Iskandar Muda Banda Aceh.

\section{Ucapan Terima Kasih}

Terima kasih yang sebesar-besarnya kepada Dr. Suastiwi Triatmodjo, M.Ds. dan M. Sholahuddin, S.Sn., M.T atas segala bentuk bimbingan dan 
arahan dalam penelitian ini. Kepada Bapak Hanafi Rais selaku Ketua Yayasan Budi Mulia Dua Yogyakarta, yang telah memberi izin untuk meneliti Masjid Kristal Khadija, Bapak Ir. H. Ahmad Fanany, selaku narasumber utama dan H. Nanang Tresnadi, selaku narasumber yang bertindak sebagai Pimpinan Proyek pembangunan MKK serta Bapak Abu Pasya selaku narasumber pendukung yang banyak membantu menyiapkan data-data yang penulis perlukan.

\section{Kepustakaan}

Ansary, Tamim. 2009. Destiny Disrupted: A History of the World through Islamic Eyes atau Dari Puncak Bagdad: Sejarah Dunia Versi Islam. terjemahan. Yuliani Liputo.2012. Jakarta: Zaman.

Ash-Shabuny, Muhammad Ali. 2002. Cahaya Al-Qur'an; Tafsir Tematik Surat An-Nuur s/d Fathir. Penerjemah Munirul Abidin, M.A. Jakarta: Pustaka Al-Kautsar.

Ching, Francis D.K. 1996. Ilustrasi Desain Interior. Terjemahan Paul Hanoto Adji. 1996. Jakarta: Erlangga.

Fanani, Ahmad. 2009. Arsitektur Mesjid. Yogyakarta: Bentang Pustaka.

Humm, Maggie. 2002. Dictionary of Feminist Theories, atau Ensiklopedia Feminisme. Terjemahan Rahayu, Mundi. Yogyakarta: Fajar Pustaka Baru.

Moleong, Lexy J. 2013. Metodologi Penelitian Kualitatif. Edisi Revisi. Cetakan ke-32. Bandung: PT Remaja Rosdakarya.

Panofsky, Erwin. 1955. Meaning of the Visual Arts. New York: Doubleday Anchor Books.

Pile, John F. 1988. Interior Design. New York: Prentice Hall

Siregar, Laksmi Gondokusumo. 2006. Makna Arsitektur Suatu Refleksi Filosofis. Jakarta: UI Press.

Situmorang, Oloan. 1993. Seni Rupa Islam: Pertumbuhan dan Perkembangannya. Bandung: Angkasa.

Sopandi, Setiadi. 2013. Sejarah Arasitektur : Sebuah Pengantar. Jakarta: PT Gramedia Pustaka Utama.
Sumalyo, Yulianto. 2000. Arsitektur Mesjid dan Monumen Sejarah Muslim. Yogyakarta: Gadjah Mada University Press.

Wiryoprawiro, M. Zein. 1986. Perkembangan Arsitektur Masjid di Jawa Timur. Surabaya: PT Bina Ilmu.

ZTF, Pradana Boy. 2005. Islam Dialektis. Malang: UMM Press

\section{Pustaka Laman}

Elisa, Irukawa. 23 September 2009. Masjid Khadija : Budi Mulia 2 Mememiliki Masjid Kristal (Online). http://snowlife-elisa.blogspot. com/2013/09/masjid-khadija-budi-mulia2-memiliki_1393.html (Akses. 3 Feb. 2014). (Admin BMD). 6 Mei 2013. Masjid Khadija atau Masjid Kristal Kebanggaan Budi Mulia Dua Akhirnya Diresmikan. (Online) http://budimuliadua.com/jogja/ index.php?option=com_content \&view=a rticle\&id=163: masjid-budi-mulia-kristalpanjen-khadjia\&catid=22: budimuliaduaterbaru\&Itemid=78. (Akses. 3 Feb. 2014).

http://id.wikipedia.org/wiki/Masjid_At-Tin (Akses, Juni 2014)

Zuraya, Nadia. (26 Sept. 2012) Peradaban Islam di Era Safawi. (Online) http://www.republika. co.id/berita/dunia-islam/khazanah/12/09/26/ mayh2t-peradaban-islam-di-era-safawi (Akses. 9 Maret 2014)

\section{Informan}

Abu Pasya (44 th.). Arsitek (Supervisor Arsitek), wawancara tanggal 10 Mei 2014, di lokasi proyek Rumah Dinas Budi Mulia Dua Panjen, Yogyakarta.

Ir. H. Ahmad Fanani (_th.). Arsitek, wawancara tanggal 20 Mei 2014, di rumah tinggal Jl. H. Ilyas, Petukangan Utara, Kebayoran Lama, Jakarta Selatan, Jakarta.

H. Nanang Tresnadi (42 th.). Pelaksana Lapangan (Site Manager Proyek Masjid Kristal Khadija/ perwakilan dari Pengelola Yayasan), wawancara tanggal 6 Mei 2014, di lokasi proyek SMK Budi Mulia Dua Panjen, Yogyakarta. 